\title{
Motif Melakukan Electronic Word Of Mouth oleh Konsumen
}
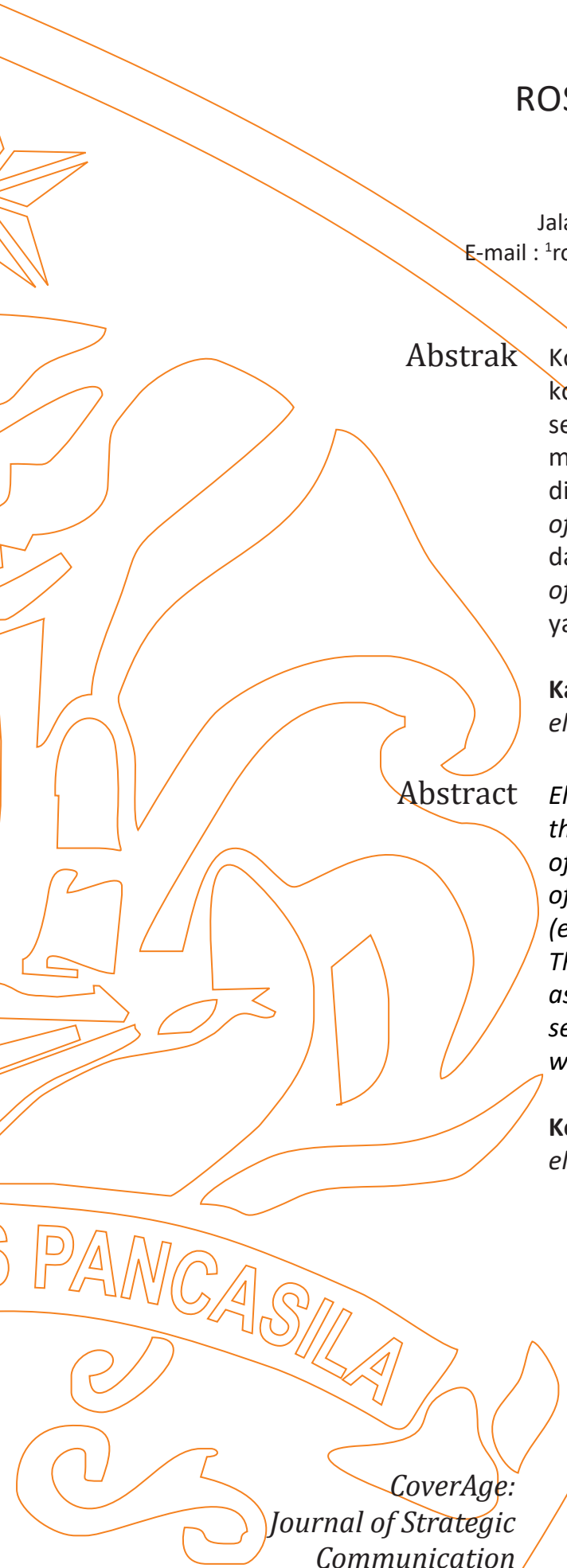

Fakultas IImu Komunikasi Universitas Pancasila

Jalan Srengseng Sawah, Jagakarsa, Jakarta Selatan 12640

ROSMALIA AHMAD ${ }^{1}$ \& DIAH FEBRINA ${ }^{2}$ 


\section{PENDAHULUAN}

Sejak awal kemunculannya, internet terus mengalami pertumbuhan pengguna. Pertumbuhan pengguna dipengaruhi dengan perubahan perilaku manusia yang ingin terhubung dengan orang lain tidak hanya di lingkungan sekitar tetapi dengan lingkungan yang lebih luas. Berdasarkan data statistik pengguna internet seluruh dunia tahun 2000-2017 mengalami pertumbuhan sebesar $976,4 \%$, dengan kata lain 3,8 Milliar orang telah mengakses internet. Di mana mayoritas pengguna internet berasal dari wilayah Asia, yaitu 49,7\%, Eropa 17\%, Amerika Latin atau Carribean 10,4\%, Afrika 10\%, Amerika Utara 8,2\%, Timur Tengah 3,8\%, dan wilayah Oceana (Australia) $0,7 \%$ (www.internetworldstats.com). Kategori negara dengan tingkat pengguna internet tertinggi di dunia menjadikan Indonesia berada pada urutan kelima yaitu $50,4 \%$ atau sebanyak 132,7 juta pengguna. Data pengguna internet tertinggi pertama adalah Cina 53\%, India 34,4\%, United States 87,9\%, dan Brazil sebesar 65,9\% (www.internetworldstats.com).

Internet memfasilitasi penggunanya melalui berbagai bentuk media baru yaitu website, blog, dan sosial media. Sosial media digunakan dengan tujuan untuk tetap terhubung, berinteraksi, dan berbagi secara online (Halligan \& Shah, 2010: 85). Kemudahan akses informasi dan murahnya biaya untuk melakukan interkoneksi internet membuat setiap orang menggunakan jejaring sosial (Abdullah, 2016: 94). Begitupun juga dengan blog yang dijadikan sebagai wadah untuk berbagi informasi, di mana blog berfokus pada topik atau pembahasan tertentu (Biagi, 2010:247). Blog lebih bersifat independen atau tanpa adanya pengaruh terutama dari perusahaan.

Pemanfaatan media baru juga dilakukan oleh perusahaan untuk menyesuaikan perubahan pola pemasaran yang terus bergerak maju dengan menggunakan teknologi. Dulu perusahanaan hanya memasarkan produknya secara tradisional dan berbiaya tinggi, tapi saat ini perusahaan telah menyediakan website sendiri. Sebuah organisasi atau perusahaan mendesain web dengan tujuan utama memasarkan produk sehingga menghasilkan nilai tambah untuk memperoleh penjualan dari situs web-nya (Hermawan, 2012: 211). Tidak hanya itu, demi melihat sebuah respon terhadap produk yang dipasarkan, perusahaan menyediakan kolom di websitenya agar konsumen dapat memberikan komentar serta ulasan terkait produk dan jasa. Secara positif ini membantu perusahaan untuk lebih mengetahui berbagai keinginan konsumen, dan menjadikannya sebagai evaluasi terhadap produk atau jasa yang ditawarkan.

Sebelum adanya internet konsumen biasanya membicarakan berbagai macam produk dan jasa secara langsung atau tatap muka. Hal ini dapat dianggap sebagai komunikasi word of mouth (WOM). Word of mouth (WOM) mempunyai sifat yang sangat persuasif, karena sumber dari komunikasi word of mouth berasal dari orang-orang disekitar seperti teman, keluarga, atau rekan kerja. Word of Mouth Marketing Association (WOMMA) mengatakan word of mouth (WOM) memberikan alasan kepada orang untuk membicarakan suatu produk atau jasa, serta mempermudah percakapan itu berlangsung (Kelly, 2007: 149).

Terjadi pergeseran terkait word of mouth (WOM) menjadi electronic word of mouth (eWOM). Litvin, et al. (2008: 461) mengatakan electronic word of mouth (eWOM) sebagai komunikasi informal yang ditujukan kepada konsumen melalui teknologi berbasis internet terkait penggunaan barang dan jasa tertentu. Komunikasi electronic word of mouth (eWOM) mempunyai kelebihan karena dapat menjangkau lebih banyak konsumen melalui media baru seperti sosial media, blog, website, dan lain sebagainya. Electronic word of mouth (eWOM) dilakukan berdasarkan pengalaman yang terkait dengan perasaan setelah menggunakan produk atau jasa. Biasanya perasaan konsumen akan mengarah pada rasa puas atau tidak setelah menggunakan produk atau jasa. Para peneliti mengatakan ketika tujuan mereka terpuaskan, orang akan mengalami perasaan positif. Sebaliknya, ketika suatu kejadian merintangi tujuan maka orang akan mengalami perasaan negatif (Mowen \& Minor, 2002: 208).

Electronic word of mouth (eWOM) mempunyai fokus kepada media baru berupa blog, website, sosial media, dan lain sebagainya. Salah satu kasus yang berkaitan dengan electronic word of mouth (eWOM) adalah ulasan di blog yang dilakukan oleh Komedian Acho mengenai apartemen Green Pramuka Jakarta. Komedian Acho menceritakan keluhannya atas ketidakjelasan dari pengurus apartemen Green Pramuka. Keluhan pertama terkait dengan pengurus apartemen Green Pramuka yang tidak memenuhi janjinya untuk memberikan sertifikat setelah dua tahun, di mana sebelumnya pengurus apartemen tersebut menjanjikan untuk memberikan sertifikat setelah dua tahun tinggal di apartemen Green Pramuka (www.megapolitankompas.com). 
Kasus tersebut menunjukkan pengalaman kurang menyenangkan dari konsumen membuatnya berinisiatif untuk membagikannya dengan membuat ulasan di blog pribadi. Seorang konsumen yang merasa senang akan mengatakan satu hal kepada konsumen lain tentang sebuah pengalaman positifnya, tapi apabila konsumen merasa tidak senang akan menceritakan sepuluh hal tentang sebuah pengalaman negatifnya kepada konsumen lain (O'Leary, 2008: 4). Tidak hanya melalui blog, konsumen juga dapat membagikan ulasan mengenai produk atau jasa di media lainnya, misalnya pada website perusahaan atau website independen.

Website independen yang saat ini banyak digunakan oleh konsumen diantaranya Mediakonsumen.com, TripAdvisor.com, dan Hometesterclub.com. Terdapat alasan kenapa konsumen mau melakukan electronic word of mouth (eWOM) dan membagikannya kepada konsumen lain. Tindakan konsumen yang melakukan electronic word of mouth (eWOM) menunjukkan adanya motivasi dari konsumen. Mowen \& Minor (2002: 208) mengatakan motivasi berkaitan dengan perasaan mencakup emosi dan suasana hati. Motivasi menjadikan orang mau melakukan sesuatu dengan harapan apa yang dilakukannya dapat berguna bagi dirinya dan orang lain.

Motivasi menjadikan orang mau melakukan sesuatu dengan harapan apa yang dilakukannya dapat berguna bagi dirinya dan orang lain. Biasanya konsumen yang melakukan electronic word of mouth (eWOM) didasarkan pada inisiatif mereka sendiri, tanpa adanya keterkaitan komersial ataupun perusahaan. Tindakan tersebut tidak mendapatkan insentif apapun dari perusahaan atau organisasi. Berbeda apabila konsumen membagikan ulasan berdasarkan keinginan dari perusahaan maka akan mendapatkan insentif. Ketika memiliki keterkaitan dengan perusahaan, maka yang melakukan adalah orang-orang yang memang memiliki pengetahuan akan produk atau jasa

Sundaram, et. al. (1998) menyebutkan beberapa motivasi konsumen melakukan electronic word of mouth (eWOM) dikembangkan dari konsep word of mouth (WOM) yaitu altruisme dan peningkatan diri. Hennig-Thurau, et al. (2004) juga mengatakan bahwa motivasi lain yang membuat konsumen melakukan electronic word of mouth (eWOM) adalah manfaat sosial dan pelampiasan perasaan. Berdasarkan uraian tersebut, penelitian ini bertujuan untuk mengetahui tingkat motivasi electronic word of mouth (eWOM) oleh konsumen. Secara khusus objektif kajian ini adalah mengetahui tingkat motivasi electronic word of mouth (eWOM) pada dimensi altruisme, peningkatan diri, manfaat sosial, dan pelampiasan perasaan.

\section{TINJAUAN PUSTAKA}

\section{Word of Mouth dan Electronic Word of Mouth}

Word of mouth (WOM) adalah komunikasi tentang sebuah produk dan jasa antara orang-orang yang bersifat independen atau tidak terkait dengan perusahaan yang menyediakan produk atau jasa (Silverman, 2001: 25). Kirby \& Marsden (2006: 164) mengatakan bahwa word of mouth (WOM) merupakan komunikasi lisan, orang ke orang, antara penerima dan komunikator yang dianggap oleh penerima sebagai non-komersial, mengenai merek, produk atau jasa. Kotler \& Keller (2009: 174) mendefinisikan word of mouth (WOM) sebagai komunikasi lisan, tertulis, dan elektronik antar masyarakat yang berhubungan dengan keunggulan atau pengalaman membeli atau menggunakan produk dan jasa.

Electronic word of mouth dikembangkan dari konsep tradisional word of mouth. Electronic word of mouth adalah proses pertukaran informasi yang dinamis dan berkelanjutan antara konsumen potensial, aktual, atau mantan konsumen mengenai produk, layanan, merek, atau perusahaan, yang tersedia untuk banyak orang dan institusi melalui internet (Ismagilova, et al., 2017: 18). Litvin, Goldsmith, \& Pan (2008: 461) mengatakan eWOM adalah semua komunikasi informal ditujukan kepada konsumen melalui teknologi berbasis internet yang terkait dengan penggunaan atau karakteristik barang dan jasa tertentu, atau penjualan mereka. HennigThuaru, et al. (2004: 39) mendefinisikan electronic word of mouth sebagai penyataan positif/negatif dibuat oleh calon pelanggan aktual atau mantan pelanggan mengenai suatu produk atau perusahaan, yang tersedia bagi banyak orang dan lembaga melalui internet.

Karakteristik komunikasi electronic word of mouth (eWOM) menjadikannya berbeda dengan komunikasi word of mouth (WOM). Perbedaannya adalah sebagai berikut :

1. Konteks, word of mouth (WOM) biasanya terjadi dalam konteks tatap muka, sementara electronic word of mouth (eWOM) berlangsung dalam konteks yang dimediasi oleh komputer yang lebih kompleks (King, et al., 2014: 3), serta menyebar melalui berbagai jenis platform yaitu email, 
pesan instan, blog, forum, komunitas online, situs review, dan lain-lain (Ismagilova, et al., 2017: 21).

2. Tie Strength, kekuatan antara pengirim dan penerima informasi juga berbeda (Ismagilova, et al., 2017: 21). Word of mouth (WOM) tradisional terjadi antara saudara, teman, dan kenalan (ikatan kuat), komunikasi electronic word of mouth (eWOM) terjadi antara orang asing (ikatan lemah) (King, et al., 2014: 5).

3. Privacy, dalam word of mouth (WOM), percakapan sebagian besar bersifat pribadi, sementara electronic word of mouth (eWOM) mereka lebih terlihat (King, et al., 2014: 3).

4. Anonimitas, dibandingkan dengan word of mouth (WOM) yang biasanya sumbernya dapat diketahui, sumber electronic word of mouth (eWOM) lebih bersifat anonim atau tidak diketahui (Pan \& Zhang, 2011: 601).

5. Ketekunan dan aksesibilitas, komunikasi electronic word of mouth (eWOM) lebih gigih dan mudah diakses untuk jangka waktu yang tidak terbatas (Cheung \& Thadani, 2010: 331).

6. Terukur, electronic word of mouth (eWOM) lebih terukur dibandingkan dengan word of mouth (WOM) tradisional. Dalam konteks ulasan online, konsumen dapat dengan mudah mengamati dan mengukur kuantitas dan kualitas opini positif dan negatif karena dimuat dalam bentuk tertulis (Lee, et al., 2008: 1).

7. Volume, Electronic word of mouth (eWOM) yang tersedia secara online lebih banyak jumlahnya dibandingkan dengan word of mouth (WOM) tradisional (Chatterjee, 2000).

Komunikasi electronic word of mouth (eWOM) terdapat beberapa kesempatan bagi konsumen antara lain: a) Dengan komunikasi electronic word of mouth (eWOM), konsumen tidak hanya memperoleh informasi tentang produk dan jasa dari orang yang mereka ketahui, tapi dapat menerima berbagai informasi tentang produk dan jasa dari sekelompok orang yang tersebar luas dan geografis yang mempunyai pengalaman tentang produk dan jasa (Jalilvand, et al., 2011: 44). b) Electronic word of mouth (eWOM) dianggap sumber alternatif bagi konsumen untuk menerima informasi tentang produk dan jasa berdasarkan pertimbangan pembeli, mengurangi pengaruh dari perusahaan dibandingkan dengan pemasaran dan periklanan tradisional (Jalilvand, et al., 2011: 44).

\section{Motivasi Electronic Word of Mouth (eWOM).}

Motivasi adalah keadaan yang diaktivasi dan digerakan di mana seseorang mengarahkan perilaku berdasarkan tujuan. Hal ini termasuk dalam dorongan keinginan, harapan dan hasrat (Mowen \& Minor, 2002: 202). Jadi penting untuk mengidentifikasi motivasi untuk memahami perilaku seseorang. Motivasi konsumen untuk terlibat dalam electronic word of mouth (eWOM) terdiri dari altruisme dan peningkatan diri (Sundaram, et al, 1998), manfaat sosial dan pelampiasan perasaan (Hennig-Thurau, et al., 2004: 42).

Altruisme merupakan tindakan melakukan sesuatu untuk orang lain tanpa mengharapkan imbalan apapun (Sundaram, et al., 1998). Altruisme bertujuan untuk meningkatkan kesejahteraan antara satu orang atau lebih selain dirinya sendiri (Batson, 1994: 603). Orang yang mempunyai motivasi altruistik secara sukarela membagikan electronic word of mouth (eWOM) kepada konsumen lain tanpa mengharapkan imbalan apapun (Cheung \& Lee, 2012:221). Altruisme juga terkait dengan kesenangan membantu konsumen lain dan perusahaan, dan itu adalah perasaan senang dari membantu orang lain (Ismagilova, et al., 2017: 34). Motivasi membantu perusahaan adalah hasil dari kepuasaan konsumen tentang produk atau jasa dan berkeinginan untuk membantu perusahaan (Ismagilova, et al., 2017: 34). Efek electronic word of mouth (eWOM) adalah perusahaan tetap menjadi sukses (Ismagilova, et al., 2017: 34).

Peningkatan diri merupakan sebuah motivasi dasar manusia (Ismagilova, et al., 2017: 34). Individu suka menampilkan diri mereka secara positif. Motivasi peningkatan diri didorong oleh keinginan seseorang untuk mendapatkan pengakuan yang positif dari orang lain (Hennig-Thurau, et al, 2004: 43). Konsumen juga membagikan electronic word of mouth (eWOM) hanya karena ingin mendapatkan sebuah pengakuan secara informal dan terlihat sebagai ahli. Selain itu, Sundaram, et al. (1998) juga mengatakan konsumen tampaknya mempunyai keinginan untuk membagikan pengalaman positif melalui komunikasi word of mouth (WOM) sebagai upaya untuk meningkatkan citranya antara lain dengan menggambarkan dirinya sebagai konsumen yang cerdas, ahli, meningkatkan status, dan mendapatkan apresiasi (Sundaram, et al, 1998).

Pelampiasan perasaan dapat membantu konsumen untuk menghadapi pengalaman negatif yang menyebabkan perasaan negatif (Ismagilova, et al., 2017: 35). Motivasi untuk terlibat dengan electronic word of mouth (eWOM) dapat mengekspresikan emosi positifnya (Sundaram, et al, 1998). Konsumen mengekspresikan emosi positifnya 
yang merupakan pengalaman konsumsi positif dari konsumen memunculkan tekanan psikologi karena berkeinginan kuat untuk membagikan pengalaman yang menyenangkan dengan orang lain (Ismagilova, et al., 2017: 35). Tekanan ini dapat dikurangi dengan membagikan electronic word of mouth (eWOM) dengan melampiaskan perasaan positifnya sebagai bagian dari pengalaman konsumsi yang sukses (Sundaram, et al., 1998). Manfaat sosial maksudnya, dengan berbagi electronic word of mouth (eWOM) di internet, konsumen dapat menjadi bagian di komunitas virtual. Tepatnya, konsumen dapat menulis komentar pada platform online karena perilaku ini menunjukkan partisipasinya dan kehadirannya dengan komunitas serta memungkinkannya untuk mendapatkan manfaat sosial dari komunitas yaitu keanggotaan (Hennig-Thurau, 2004: 42).

Komunikasi electronic word of mouth (eWOM) juga mempunyai beberapa karakteristik yaitu volume dan jangkauan serta hasil electronic word of mouth (eWOM) dipengaruhi oleh penyebaran di platform. Volume dan jangkauan electronic word of mouth (eWOM) belum pernah terjadi sebelumnya (Dellarocas, 2003: 1407). Komunikasi elctronic word of mouth (eWOM) mampu menjangkau sejumlah besar orang dalam waktu singkat (King, et al., 2014: 4). Hasil electronic word of mouth (eWOM) dipengaruhi oleh penyebaran di platform, yang didefinisikan sebagai sejauh mana percakapan terkait produk terjadi di berbagai komunitas (Godes \& Mayzlin, 2004: 546). Akibatnya, sifat platform dapat berdampak besar pada kejadian dan evolusi eWOM (misalnya produk yang dibahas dan seberapa sering) (Ismagilova, et al., 2017: 20).

\section{METODE}

Penelitian dilakukan menggunakan pendekatan kuantitatif deskriptif melalui survei terhadap 100 konsumen yang pernah melakukan eWOM. Pendekatan kuantitatif mementingkan adanya variabel-variabel sebagai objek penelitian, dan variabel-variabel tersebut harus didefinisikan dalam bentuk operasionalisasi dari masing-masing variabel (Siregar, 2013: 30). Data dikumpulkan dengan menyebarkan kuesioner online dengan link http://goo.gl/forms/VlhLfum9BHOFhyv73 melalui facebook, line, whatsapp, dan messenger yang dimulai dari tanggal 25 Desember 2017 hingga 31 Desember 2017 . Purposive sampling digunakan sebagi teknik penarikan sampel. Teknik ini merupakan metode penetapan responden untuk dijadikan sampel berdasarkan pada kriteria-kriteria tertentu (Siregar, 2013: 60).

Penelitian ini menggunakan satu variabel berupa pengukuran tingkat motivasi electronic word of mouth (eWOM) oleh konsumen yang terdiri dari empat dimensi yaitu altruisme, peningkatan diri, manfaat sosial, dan pelampiasan perasaan. Keempat dimensi mengacu kepada Sundaram, et al. (1998) dan Hennig-Thurau, et al. (2004). Berikut adalah definisi operasional atas variabel sebagai berikut :

\section{Altruisme (altruism)}

Altruisme merupakan tindakan melakukan sesuatu untuk orang lain tanpa mengharapkan imbalan apapun. Dalam dimensi altruisme mempunyai tiga indikator diantaranya sebagai berikut:

a. Keinginan dalam membantu orang lain diukur atau dilihat dari dua pernyataan yaitu:

1) Keinginan konsumen membagikan electronic word of mouth (eWOM) dengan sukarela.

2) Berkeinginan membantu konsumen lain ketika membagikan electronic word of mouth (eWOM).

b. Perhatian kepada konsumen lain dapat diukur atau dilihat menggunakan tiga pernyataan yaitu:

1) Konsumen melakukan kegiatan electronic word of mouth (eWOM) untuk memperingatkan konsumen lain tentang keburukan produk.

2) Membagikan electronic word of mouth (eWOM) untuk menyelamatkan orang lain atas pengalaman negatif.

3) Membagikan electronic word of mouth (eWOM) agar orang lain membeli produk yang tepat.

c. Membantu perusahaan dapat dilihat atau diukur menggunakan dua pernyataan yaitu:

1) Membagikan electronic word of mouth (eWOM) untuk membantu perusahaan.

2) Membagikan electronic word of mouth (eWOM) untuk memberikan dukungan kepada perusahaan.

2. Peningkatan Diri

Peningkatan diri adalah tindakan konsumen membagikan pengalaman positif melalui komunikasi word of mouth (WOM) sebagai upaya untuk meningkatkan citranya antara lain dengan menggambarkan dirinya sebagai konsumen yang cerdas, ahli, meningkatkan status, dan 
mendapatkan apresiasi. Dimensi peningkatan diri mempunyai tiga indikator yaitu:

a. Indikator dianggap sebagai pembelanja yang cerdas/meningkatkan status diukur menggunakan dua pernyataan yaitu:

1) Membagikan electronic word of mouth (eWOM) agar dianggap sebagai ahli.

2) Membagikan electronic word of mouth (eWOM) untuk menunjukkan pengetahuan tentang sebuah produk.

b. Indikator mendapatkan pengakuan sebagai ahli diukur menggunakan satu pernyataan yaitu membagikan electronic word of mouth (eWOM) agar dianggap sebagai ahli.

c. Indikator mendapatkan apresiasi diukur menggunakan satu pernyataan yaitu membagikan electronic word of mouth (eWOM) untuk mendapatkan apresiasi oleh pihak lain.

3. Manfaat Sosial

Manfaat sosial adalah tindakan berbagi electronic word of mouth (eWOM), di mana konsumen dapat menjadi bagian di komunitas virtual. Dimensi manfaat sosial memiliki tiga indikator yaitu bagian dari komunitas virtual, sebagai bentuk partisipasi, dan sebagai bentuk kesamaan pikiran sebagai konsumen.

a. Indikator bagian dari komunitas virtual diukur menggunakan satu pernyataan yaitu membagikan electronic word of mouth (eWOM) tentang produk untuk menjadi bagian di komunitas virtual.

b. Indikator sebagai bentuk partisipasi diukur menggunakan satu pernyataan yaitu membagikan electronic word of mouth (eWOM) tentang produk sebagai bentuk partisipasi.

c. Indikator sebagai bentuk kesamaan pikiran sebagai konsumen diukur menggunakan satu pernyataan, yaitu membagikan electronic word of mouth (eWOM) tentang produk sebagai bentuk kesamaan pemikiran.

4. Pelampiasan Perasaan

Pelampiasan perasaan adalah motivasi untuk terlibat dengan berbagi electronic word of mouth (eWOM) dapat mengekspresikan emosi positif, menghadapi pengalaman negatif yang menyebabkan perasaan negatif. Dimensi pelampiasan perasaan mempunyai tiga indikator yaitu:

a. Indikator mengekspresikan perasaan positif atau negatif dari sebuah produk diukur menggunakan dua pernyataan:
1) Membagikan electronic word of mouth (eWOM) positif tentang produk.

2) Membagikan electronic word of mouth (eWOM) negatif tentang produk.

b. Indikator mengekspresikan perasaan positif/ negatif agar diketahui perusahaan diukur menggunakan dua pernyataan yaitu:

1) Membagikan electronic word of mouth (eWOM) positif agar diketahui perusahaan yang bersangkutan.

2) Membagikan electronic word of mouth (eWOM) negatif agar diketahui perusahaan yang bersangkutan.

c. Indikator sebagai bentuk kepuasan/ ketidakpuasan setelah menggunakan produk diukur menggunakan dua pernyataan, yaitu:

1) Membagikan electronic word of mouth (eWOM) positif sebagai bentuk kepuasan.

2) Membagikan electronic word of mouth (eWOM) negatif sebagai bentuk ketidakpuasan.

\section{HASIL DAN PEMBAHASAN}

\section{- Karakteristik Responden}

Berdasarkan tabel 1 dari 100 konsumen yang melakukan electronic word of mouth (eWOM) menunjukkan responden perempuan memiliki persentase paling banyak yaitu $71 \%$. Sedangkan, $29 \%$ merupakan responden laki-laki. Terlihat rentan usia 20-21 dan 22-23 memperoleh hasil yang sama yaitu 31\%, Usia 18-19 sekitar 17\%, 24-25 tahun sebesar 16\%. Usia lainnya mendapatkan hasil 5\%.

Temuan penelitian untuk pendidikan terakhir, mayoritas responden yang terlibat dalam electronic word of mouth (eWOM) adalah responden yang memiliki pendidikan terakhir SMA/sederajat dengan perolehan sebesar 53\%. Hasil lainnya yang cukup bagus terdapat pada responden dengan tingkat pendidikan S1 yaitu sekitar 43\% responden juga terlibat dalam electronic word of mouth (eWOM). Diploma mendapatkan hasil sebesar 3\% dan S2 memperoleh hasil $1 \%$.

\section{Frekuensi Penggunaan Media baru}

Tabel 2 menunjukkan frekuensi penggunaan media baru dalam melakukan electronic word of mouth (eWOM). Data menyebutkan 36\% responden memilih instagram sebagai media baru yang sering digunakan. Selanjutnya, $27 \%$ responden mengungkapkan media baru yang sangat sering digunakan adalah whatsapp. Hasil 
Tabel 1. Karakteristik Responden

\begin{tabular}{lccc}
\hline & & Frekuensi & Persentase \\
\hline Jenis Kelamin & & 29 & $29 \%$ \\
& Laki-Laki & 71 & $71 \%$ \\
Perempuan & 100 & $100 \%$ \\
Jumlah & & \\
& & 17 & $17 \%$ \\
$20-21$ & 31 & $31 \%$ \\
$22-23$ & 31 & $31 \%$ \\
$24-25$ & 16 & $16 \%$ \\
Lainnya & 5 & $5 \%$ \\
Jumlah & 100 & $100 \%$ \\
Pendidikan Terakhir & & \\
SMA/Sederajat & 53 & $53 \%$ \\
Diploma & 3 & $3 \%$ \\
S1 & 43 & $43 \%$ \\
S2 & 1 & $1 \%$ \\
Jumlah & 100 & $100 \%$ \\
\hline
\end{tabular}

Tabel 2. Frekuensi Penggunaan Media Baru

\begin{tabular}{llcccc}
\hline No & Media Baru & $\begin{array}{c}\text { Tidak Pernah } \\
\%\end{array}$ & $\begin{array}{c}\text { Sekali-Sekali } \\
\%\end{array}$ & $\begin{array}{c}\text { Sering } \\
\%\end{array}$ & $\begin{array}{c}\text { Sangat Sering } \\
\%\end{array}$ \\
\hline 1 & Blog & $46 \%$ & $44 \%$ & $9 \%$ & $1 \%$ \\
2 & Facebook & $24 \%$ & $51 \%$ & $18 \%$ & $7 \%$ \\
3 & Instagram & $15 \%$ & $38 \%$ & $36 \%$ & $11 \%$ \\
4 & Line & $23 \%$ & $40 \%$ & $22 \%$ & $15 \%$ \\
5 & Twitter & $44 \%$ & $42 \%$ & $9 \%$ & $5 \%$ \\
6 & Whatsapp & $15 \%$ & $33 \%$ & $25 \%$ & $27 \%$ \\
7 & Website & $38 \%$ & $43 \%$ & $13 \%$ & $6 \%$ \\
8 & Youtube & $38 \%$ & $38 \%$ & $18 \%$ & $6 \%$ \\
\hline
\end{tabular}

Frekuensi membagikan ulasan, komentar dan Kritik

Tabel 3. Frekuensi Membagikan Ulasan, Komentar, dan Kritik

\begin{tabular}{clcccc}
\hline No & Pernyataan & $\begin{array}{c}\text { Tidak Pernah } \\
\%\end{array}$ & $\begin{array}{c}\text { Sekali-Sekali } \\
\%\end{array}$ & $\begin{array}{c}\text { Sering } \\
\%\end{array}$ & $\begin{array}{c}\text { Sangat Sering } \\
\%\end{array}$ \\
\hline 1 & Ulasan & $15 \%$ & $64 \%$ & $17 \%$ & $4 \%$ \\
2 & Komentar & $13 \%$ & $63 \%$ & $22 \%$ & $2 \%$ \\
3 & Kritik & $20 \%$ & $66 \%$ & $13 \%$ & $1 \%$ \\
\hline
\end{tabular}


lainnya memperlihatkan sekitar 51\% responden hanya sekali-sekali menggunakan facebook ketika melakukan electronic word of mouth (eWOM). Begitupun dengan blog yaitu $46 \%$ responden memilih tidak pernah menggunakannya. Hasil ini menjadikan Instagram sebagai media baru yang paling banyak digunakan oleh mayoritas responden ketika melakukan electronic word of mouth (eWOM). Sebaliknya, mayoritas responden sepakat bahwa media baru paling tidak pernah digunakan oleh responden adalah blog.

Tabel 3 mendeskripsikan temuan penelitian tentang frekuensi membagikan ulasan, komentar, dan kritik. Temuan menunjukkan bahwa responden tidak terlalu sering memberikan kritik tentang sebuah produk yaitu $66 \%$ responden memilih sekali-sekali. $64 \%$ responden juga memilih hanya sekali-sekali memberikan ulasan tentang produk. Hasil menarik lainnya juga menyatakan bahwa, 22\% responden menyebutkan sering memberikan komentar tentang produk X.

Tabel 4. Frekuensi Berbagi Pengalaman

\begin{tabular}{cc}
\hline & Frekuensi \% \\
\hline 1-3 Kali & $61 \%$ \\
3-6 kali & $24 \%$ \\
7-9 kali & $10 \%$ \\
9-12 kali & $5 \%$ \\
\hline Jumlah & $100 \%$ \\
\hline
\end{tabular}

Tabel 4 mengungkapkan $61 \%$ responden membagikan pengalamannya tentang produk sebanyak 1-3 dalam sebulan. $24 \%$ juga membagikan 3-6. Temuan lainnya menyebutkan $10 \%$ responden membagikan 7-9 dalam waktu satu bulan. Rentan membagikan pengalaman 9-12 kali mendapatkan hasil paling sedikit 5\%. Temuan ini menunjukkan konsumen hanya sekali-sekali memberikan ulasan, komentar, serta kritik melalui media baru yaitu website, blog, sosial media. Kemudian, dari segi frekuensi membagikan membagikann pengalamannya, mayoritas hanya melakukan sebanyak 1-3 kali dalam satu bulan.

\section{Tingkat Motivasi Electronic Word of Mouth (eWOM)}

Penelitian ini membahas tentang motivasi electronic word of mouth (eWOM) oleh konsumen yang diawali dengan membahas konsep dasarnya word of mouth (WOM), kemudian electronic word of mouth (eWOM) serta terdapat empat motivasi dari electronic word of mouth (eWOM), yaitu altruisme, peningkatan diri, manfaat sosial, dan pelampiasan perasaan. Motivasi bersumber dari konsep oleh Sundaram, et al. (1998) dan Hennig-Thurau, et al. (2004).

\section{a. Dimensi Altruisme}

Temuan penelitian pada tabel 5 menunjukkan bahwa sebagian besar responden memberikan pilihan setuju terhadap pernyataan tentang ingin membantu konsumen lain ketika membagikan ulasan/komentar/kritik/pengalaman tentang produk $\mathrm{X}$, yaitu sebesar $78 \%$. Temuan menarik lainnya menyebutkan responden menyatakan sangat setuju dengan membagikan ulasan/ komentar/kritik/pengalaman tentang produk $X$ agar orang lain membeli produk yang tepat, yaitu sebanyak 28\%. Namun, hasil sebaliknya menemukan sekitar 30\% responden tidak setuju terhadap pernyataan apabila membagikan ulasan/komentar/kritik/pengalaman tentang produk $\mathrm{X}$ untuk membantu perusahaan produk $\mathrm{X}$ berhasil.

Berdasarkan analisis desktriptif dimensi altruisme ditemukan konsumen memiliki motivasi melakukan electronic word of mouth (eWOM) untuk semua pernyataan yang diberikan. Salah satunya mayoritas responden memilih setuju dengan pernyataan membagikan ulasan/ komentar/kritik/pengalaman tentang produk $\mathrm{X}$ untuk membantu perusahaan produk $X$ berhasil. Hal ini selaras dengan pernyataan Ismagilova, et al. (2017: 34) efek motivasi electronic word of mouth (eWOM) agar perusahaan tetap menjadi sukses.

Temuan ini juga memiliki kesesuaian dengan penelitian Pourabedin \& Migin (2015), yaitu membantu perusahaan hotel adalah motivasi konsumen menulis ulasan online. Selain itu, pilihan setuju juga terlihat pada pernyataan ingin membantu konsumen lain ketika membagikan ulasan/komentar/kritik/pengalaman tentang produk $X$ memperoleh nilai persentase yang tinggi, serta sesuai pada penelitian berasal dari Yoo \& Gretzel (2008) mengungkapkan perhatian kepada konsumen lain memotivasi konsumen melakukan electronic word of mouth (eWOM) dengan menulis ulasan online terkait perjalanan. Penelitian yang dilakukan oleh Porabedin \& Migin pada tahun 2015 juga menyebutkan bahwa keinginan untuk membantu pelanggan lain adalah salah satu motivasi konsumen dalam menyebarkan electronic word of mouth (eWOM) positif. 
Tabel 5. Dimensi Altruisme

\begin{tabular}{lcccc}
\hline \multicolumn{1}{c}{ Pernyataan } & STS & TS & S & SS \\
\hline $\begin{array}{l}\text { Saya ingin membantu konsumen lain ketika membagikan } \\
\text { ulasan/komentar/kritik/pengalaman ten-tang produk X. }\end{array}$ & $1 \%$ & $5 \%$ & $87 \%$ & $7 \%$ \\
$\begin{array}{l}\text { Saya membagikan ulasan/komentar/kritik/pengalaman } \\
\text { untuk memperingatkan orang lain tentang keburukan }\end{array}$ & $1 \%$ & $16 \%$ & $65 \%$ & $18 \%$ \\
produk X. & & & & \\
$\begin{array}{l}\text { Saya membagikan ulasan/komentar/kritik/pengalaman } \\
\text { tentang produk X untuk menyelamatkan orang lain atas }\end{array}$ & $1 \%$ & $7 \%$ & $69 \%$ & $23 \%$ \\
$\begin{array}{l}\text { Sengalaman negatif yang sama dengan saya. } \\
\begin{array}{l}\text { tentang produk X agar orang lain membeli produk yang } \\
\text { tepat. }\end{array}\end{array}$ & $1 \%$ & $4 \%$ & $67 \%$ & $28 \%$ \\
$\begin{array}{l}\text { Saya membagikan ulasan/komentar/kritik/pengalaman } \\
\text { tentang produk X untuk membantu perusahaan produk } \\
\text { X berhasil. }\end{array}$ & $6 \%$ & $30 \%$ & $56 \%$ & $8 \%$ \\
$\begin{array}{l}\text { Saya membagikan ulasan/komentar/pengalaman } \\
\text { tentang produk X untuk memberi dukungan kepada } \\
\text { perusahaan produk X. }\end{array}$ & $5 \%$ & $27 \%$ & $63 \%$ & $5 \%$ \\
\hline
\end{tabular}

Tabel 6. Dimensi Peningkatan Diri

\begin{tabular}{lcccc}
\hline \multicolumn{1}{c}{ Pernyataan } & $\begin{array}{c}\text { STS } \\
\%\end{array}$ & $\begin{array}{c}\text { TS } \\
\%\end{array}$ & $\begin{array}{c}\text { S } \\
\%\end{array}$ & $\begin{array}{c}\text { SS } \\
\%\end{array}$ \\
\hline $\begin{array}{l}\text { Saya membagikan ulasan/komentar/kritik/pengalaman } \\
\text { tentang produk X agar dianggap sebagai orang yang cerdas. }\end{array}$ & $15 \%$ & $52 \%$ & $32 \%$ & \\
$\begin{array}{l}\text { Saya membagikan ulasan/komentar/kritik/pengalaman } \\
\text { untuk menunjukkan pengetahuan tentang produk X. }\end{array}$ & $3 \%$ & $16 \%$ & $74 \%$ \\
$\begin{array}{l}\text { Saya membagikan ulasan/komentar/kritik/pengalaman } \\
\text { agar dianggap sebagai ahli atas produk X. }\end{array}$ & $15 \%$ & $56 \%$ & $27 \%$ \\
$\begin{array}{l}\text { Saya membagikan ulasan/komentar/kritik/pengalaman } \\
\text { tentang produk X untuk mendapatkan perasaan diapresiasi } \\
\text { oleh pihak lain. }\end{array}$ & $14 \%$ & $50 \%$ & $32 \%$ \\
\hline
\end{tabular}

\section{b. Dimensi Peningkatan Diri}

Analisis deskrtipif untuk dimensi peningkatan diri menggambarkan bahwa sebesar 56\% responden memilih tidak setuju dengan pernyataan membagikan ulasan/ komentar/ kritik/pengalaman agar dianggap sebagai ahli atas produk X. Hasil menarik lainnya, memperlihatkan $52 \%$ lebih dari setengah responden menyatakan tidak setuju apabila membagikan ulasan/ komentar/pendapat/kritik/pengalaman tentang produk $\mathrm{X}$ agar dianggap sebagai orang yang cerdas. Selain itu, setengah responden (50\%) memberikan pilihan tidak setuju terhadap pernyataan membagikan ulasan/komentar/ kritik/pengalaman tentang produk $\mathrm{X}$ untuk mendapatkan perasaan diapresiasi pihak lain.

Temuan penelitian di atas menemukan hasil yang didominasi oleh pilihan tidak setuju dari responden. Hal ini terlihat pada pernyataan pertama yang memiliki nilai persentase tertinggi, di mana mayoritas responden menyatakan tidak setuju dengan pernyataan membagikan ulasan/ komentar/kritik/pengalaman agar dianggap sebagai ahli atas produk $X$. Temuan penelitian memiliki kesamaan dengan penjelasan dari Hennig-Thurau, et al. (2004: 43), konsumen juga membagikan electronic word of mouth (eWOM) hanya karena ingin mendapatkan sebuah 
pengakuan secara informal dan terlihat sebagai ahli.

\section{c. Dimensi Manfaat Sosial}

Tabel 7 memberikan hasil penelitian yang membuktikan lebih dari setengah responden atau 79\% memilih setuju atas pernyataan membagikan ulasan/komentar/kritik/pengalaman tentang produk sebagai bentuk partisipasi mereka yaitu sebesar. Temuan lainnya menyebutkan sebanyak $41 \%$ responden memberikan pilihan tidak setuju terkait pernyataan membagikan ulasan/ komentar/kritik/pengalaman tentang produk $\mathrm{X}$ untuk menjadi bagian di komunitas virtual. Hasil terakhir dengan persentase terendah yaitu 11\% responden sangat setuju apabila membagikan ulasan/komentar/kritik/pengalaman tentang produk $X$ sebagai bentuk kesamaan pemikiran sebagai konsumen.

Temuan analisis deskriptif dimensi manfaat sosial menemukan lebih dari setengah responden memilih setuju pada semua pernyataan. Temuan ini sesuai dengan apa yang dikatakan oleh Hennig-Thurau, et al. (2004: 42), dengan berbagi electronic word of mouth (eWOM) di internet, konsumen dapat menjadi bagian di komunitas virtual. Tepatnya, konsumen dapat menulis komentar pada platform online karena perilaku ini menunjukkan partisipasinya dan kehadirannya dengan komunitas serta memungkinkan untuk mendapatkan manfaat sosial dari komunitas yaitu keanggotaan. Artinya dapat disimpulkan bahwa dimensi manfaat sosial menjadi motivasi konsumen melakukan electronic word of mouth (eWOM).

\section{d. Pelampiasan Perasaan}

Tabel 8. menguraikan hasil analisis deskriptif pada dimensi pelampiasan perasaan. Dalam dimensi tersebut responden memberikan respon yang sangat baik pada pilihan setuju dengan jumlah persentase responden masing-masing penyataan di atas 50\%. Temuan penelitian mengungkapkan pilihan tertinggi sebesar $78 \%$, artinya sebagian besar responden memberikan pilihan setuju pada pernyataan membagikan ulasan/komentar/ kritik/pengalaman positif tentang produk $X$. Sama halnya dengan pernyataan nomor enam tentang membagikan ulasan/komentar/kritik/ pengalaman positif tentang produk $X$ sebagai bentuk kepuasan terhadap produk $X$, di mana $76 \%$ responden memilih setuju dengan pernyataan tersebut. Hasil sebaliknya, memperlihatkan perolehan sebesar $31 \%$ responden memilih tidak setuju dengan pernyataan membagikan ulasan/ komentar/kritik/pengalaman negatif tentang produk X.

Dimensi pelampiasan perasaan menemukan mayoritas responden menyatakan setuju dengan pernyataan yang diberikan. Salah satunya adalah pernyataan membagikan ulasan/komentar/ kritik/pengalaman positif dan negatif tentang produk $X$. Temuan tersebut dinyatakan sesuai dengan penjelasan oleh Ismagilova, et al. (2017: 7) yang mengungkapkan bahwa komunikasi word of mouth (eWOM) bisa menjadi positif atau negatif. Begitupun dengan sebagian besar responden memberikan pilihan setuju pada penyataan membagikan ulasan/komentar/ kritik/pengalaman positif sebagai bentuk kepuasan terhadap produk $\mathrm{X}$. Hal senada juga diungkapkan oleh Ismagilova, et al. (2017: 7) di mana word of mouth (WOM) positif terjadi ketika

Tabel 7. Analisis Deskriptif Dimensi Manfaat Sosial

\begin{tabular}{lccccc}
\hline \multicolumn{1}{c}{ Pernyataan } & $\begin{array}{c}\text { STS } \\
\%\end{array}$ & $\begin{array}{c}\text { TS } \\
\%\end{array}$ & $\begin{array}{c}\text { S } \\
\%\end{array}$ & $\begin{array}{c}\text { SS } \\
\%\end{array}$ & $\begin{array}{c}\text { Total } \\
\%\end{array}$ \\
\hline $\begin{array}{l}\text { Saya membagikan ulasan/komentar/kritik/ } \\
\text { pengalaman tentang produk sebagai bentuk } \\
\text { partisipasi. }\end{array}$ & $4 \%$ & $8 \%$ & $79 \%$ & $9 \%$ & $100 \%$ \\
$\begin{array}{l}\text { Saya membagikan ulasan/komentar/ } \\
\text { kritik/pengalaman tentang produk X untuk } \\
\text { menjadi bagian di komunitas virtual. }\end{array}$ & $7 \%$ & $41 \%$ & $45 \%$ & $7 \%$ & $100 \%$ \\
$\begin{array}{l}\text { Saya membagikan ulasan/komentar/kritik/ } \\
\text { pengalaman tentang produk X sebagai } \\
\text { bentuk kesamaan pikiran sebagai konsumen. }\end{array}$ & $3 \%$ & $10 \%$ & $76 \%$ & $11 \%$ & $100 \%$ \\
\hline
\end{tabular}


Tabel 8. Dimensi Pelampiasan Perasaan

\begin{tabular}{lcccc}
\hline \multicolumn{1}{c}{ Pernyataan } & STS (\%) & TS (\%) & S (\%) & SS (\%) \\
\hline $\begin{array}{l}\text { Saya membagikan ulasan/komentar/kritik/ } \\
\text { pengalaman positif tentang produk X. }\end{array}$ & $1 \%$ & $7 \%$ & $78 \%$ & $14 \%$ \\
$\begin{array}{l}\text { Saya membagikan ulasan/komentar/kritik/ } \\
\text { pengalaman negatif tentang produk X }\end{array}$ & $3 \%$ & $31 \%$ & $57 \%$ & $9 \%$ \\
$\begin{array}{l}\text { Saya membagikan ulasan/komentar/kritik/ } \\
\text { pengalaman positif tentang produk X agar }\end{array}$ & $3 \%$ & $21 \%$ & $65 \%$ & $11 \%$ \\
$\begin{array}{l}\text { diketahui perusahaan yang bersangkutan. } \\
\text { Saya membagikan ulasan/komentar/kritik/ }\end{array}$ & & & & \\
$\begin{array}{l}\text { pengalaman negatif tentang produk X agar } \\
\text { diketahui perusahaan yang bersangkutan. }\end{array}$ & $5 \%$ & $21 \%$ & $59 \%$ & $15 \%$ \\
$\begin{array}{l}\text { Saya membagikan ulasan/komentar/kritik/ } \\
\text { pengalaman positif tentang produk X sebagai } \\
\text { bentuk kepuasan terhadap produk X. }\end{array}$ & $3 \%$ & $3 \%$ & $76 \%$ & $18 \%$ \\
$\begin{array}{l}\text { Saya membagikan ulasan/komentar/kritik/ } \\
\text { pengalaman negatif tentang produk X sebagai } \\
\text { bentuk ketidakkepuasan terhadap produk X. }\end{array}$ & $4 \%$ & $15 \%$ & $63 \%$ & $18 \%$ \\
\hline
\end{tabular}

Tabel 9. Tingkat Motivasi Ewom

\begin{tabular}{lccc}
\hline \multirow{2}{*}{ Dimensi } & \multicolumn{2}{c}{ Skala } & \multirow{2}{*}{ Total } \\
\cline { 2 - 3 } & Rendah (\%) & Tinggi (\%) & \\
\hline Altrusme & $6 \%$ & $94 \%$ & $100 \%$ \\
Peningkatan Diri & $63 \%$ & $37 \%$ & $100 \%$ \\
Manfaat Sosial & $19 \%$ & $81 \%$ & $100 \%$ \\
Pelampiasan Perasaan & $25 \%$ & $75 \%$ & $100 \%$ \\
Semua Dimensi & $18 \%$ & $82 \%$ & $100 \%$ \\
\hline
\end{tabular}

konsumen merasa puas dengan sebuah produk atau jasa kemudian membagikannya kepada konsumen lainnya. Responden juga setuju pada penyataan membagikan ulasan/komentar/ kritik/pengalaman negatif sebagai bentuk ketidakpuasan terhadap produk X. Hasil temuan penelitian sejalan dengan yang dijelaskan oleh Richin (1983: 71) word of mouth (WOM) negatif adalah respon konsumen terhadap ketidakpuasan dengan produk atau layanan.

Pada tabel 9 menunjukkan bahwa tingkat motivasi responden pada dimensi altruisme sangat tinggi yaitu $94 \%$. Motivasi konsumen pada dimensi peningkatan diri berada pada skala rendah sebesar $63 \%$. Tidak hanya itu, tingkat motivasi konsumen dimensi manfaat sosial memiliki skala tinggi yaitu $81 \%$. Begitupun dengan tingkat motivasi konsumen pada dimensi pelampiasan menunjukkan hasil yang sangat tinggi yaitu $75 \%$. Secara keseluruhan, tingkat motivasi electronic word of mouth (eWOM) konsumen terhadap semua dimensi adalah tinggi dengan persentase sebesar $82 \%$.

Hasil penelitian yang menjelaskan empat motivasi electronic word of mouth (eWOM) memiliki keterkaitan satu sama lainnya. Keterkaitan dengan membuat urutan motivasi electronic word of mouth (eWOM) yang diawali dari motivasi pelampiasan perasaan, altruisme, manfaat sosial, dan peningkatan diri. Kemudian penjelasan dilakukan di mana secara keseluruhan konsumen membagikan ulasan/komentar/kritik/pengalaman positif atau negatif sebagai bentuk kepuasan/ ketidakpuasan mereka setelah menggunakan produk karena ingin membantu konsumen dengan cara memberikan peringatan tentang keburukan produk untuk menyelamatkan konsumen lain atas pengalaman negatif yang sama sebagai konsumen agar dapat membeli produk yang tepat.

Secara tidak langsung agar diketahui perusahaan yang bersangkutan dan dianggap 
sebagai bentuk dukungan serta membantu perusahaan menjadi berhasil. Konsumen yang melakukan eWOM mendapatkan manfaat sosial dengan menjadi bagian di komunitas virtual karena telah menunjukkan partisipasinya yang memiliki kesamaan pikiran sebagai konsumen. Konsumen juga membagikan pengalamannya hanya untuk menunjukkan pengetahuan tentang produk, dan tidak ingin dianggap sebagai orang yang cerdas, ahli, dan mendapatkan apresiasi dari orang lain. Konsumen juga memiliki tingkat motivasi melakukan eWOM yang tinggi terhadap dimensi altrusime, manfaat sosial, pelampiasan perasaan, dan untuk peningkatan diri mempunyai motivasi rendah.

\section{SIMPULAN}

Berdasarkan uraian temuan penelitian dan pembahasan, maka dapat disimpulkan sebagai berikut: dimensi altruisme, manfaat sosial, dan pelampiasan dianggap sebagai motivasi konsumen melakukan electronic word of mouth (eWOM). Hal ini diperkuat dengan tingkat motivasi ketiganya yang tinggi. Sebaliknya, peningkatan diri adalah dianggap tidak menyebabkan konsumen termotivasi melakukan electronic word of mouth (eWOM), karena memiliki tingkat motivasi electronic word of mouth (eWOM) yang rendah.

\section{DAFTAR PUSTAKA}

Abdullah, M. (2016). Manajemen Komunikasi Periklanan. Yogyakarta: Aswaja Pressindo.

Batson, C.B. (1994). Why Act for The Public Good? Four Answer. Society for Personality and Social Psychology, 20: 603-610.

Biagi, S. (2010). Media/Impact: Pengantar Media Massa. Jakarta: Salemba Humanika.

Chatterjee, P. (2001). Online Reviews: Do Consumer Use Them. Advences in Consumer Research, 28: 129-133.

Cheung, C.M.K. \& Lee, M.K.O. (2012). What Drive Consumer to Spread Electronic Word of Mouth in Online Consumer-Opinion Platform. Decision Support Systems, 53(51): 218-225.

\& Thadani, D.R. (2012)._The impact of electronic word-of-mouth communication: A literature analysis and integrative model. Decision Support Systems, 54.
Dellarocas, C. (2003). The Digitalization of Word of Mouth: Promise and Challenges of Online Feedback Mechanisms. Management Science, 49: 10

Godes, D. \& Mayzlin D. (2004). Using Online Conversations to Study Word-of-Mouth Communication. Marketing Science, 23 (4): 545560. Diakses dari doi 10.1287/mksc.1040.0071.

Halligan, B. \& Shah, D. (2010). Inbound Marketing: Get Found Using Google, Social Media, and Blogs. New Jersey: John Wiley \& Sons, Inc.

Hennig-Thurau, T., Gwinner, K.P., Walsh, G., \& Gremler, D.D. (2004). Electronic Word of Mouth via Consumer Opinion Platform: What Motivates Consumer to Articulate Themselves on The Internet?. Journal of Interactive Marketing, 8(1): 38-52.

Hermawan, A. (2012). Komunikasi Pemasaran. Jakarta: Erlangga.

Internet Workstats. Internet Uses In The World by Region-June 30, 2017. Diakses 18 Januari 2018, pukul 20.00 WIB dari http://www. internetworldstats.com/stats.htm,.

Internet Worldstats. The World Population and The Top Ten Country With The Highest Population. Diakses 18 Januari 2018, pukul 20.25. WIB dari http://www.internetworldstats.com/stats8. htm.

Ismagilova, E., Slade, E., Dwivedi, Y. K., \& William, M. D. (2017). Electronic Word of Mouth (EWOM) in the Mareketing Context. Switzerland: Springer Nature.

Jalilvand, M.R., Esfahani, S.S., \& Samiei, N. (2011). Electronic Word of Mouth: Challenge and Opportunity. Procedia Computer Science. 42-46.

Kelly, K. (2007). Beyond Buzz The Next Generation of Word of Mouth Marketing. New York: Amacom.

King, R.A., Racherla, P., \& Bush, V.D. (2014). What We Know and Don't Know About Online Word of Mouth: A Review and Synhesis of the Literature. Journal of Interactive Marketing. 1-17.

Kirby, J. \& Marsden, P. (2006). Connected Marketing The Viral, Buzz and Word of Mouth Revolution. Elsevier Linacre House, Jordan Hill, Oxford. ., \& Keller, K.L. (2009). Manajemen Pemasaran. Jakarta: Erlangga.

Lee, J., Park, D.H., \& Han, I. (2008). The Effect of Negative Online Consumer Reviews on Product Attitude: An Information Processing View. Electronic Research and Applications, 7: 341- 
352. Doi: 10.1016/j.elerap.2007.05.004.

Litvin, S.W., Goldsmith, R.E., \& Pan B. (2008). Electronic Word of Mouth in Hospitality and Tourism Management. Tourism Management. 458-468.

Mowen, J. C. \& Minor, M. (2002). Perilaku Konsumen . Jakarta: Erlangga.

O'Leary, S. \& Sheehan, K. (2008). Building Buzz to Beat the Big Boys: Word of Mouth Marketing for Small Businesses. Wesport: Praeger Publishers.

Pan, Y. \& Zhang, J.Q. (2011). Born Unequal: A Study of the Helpfulness of User-Generated Product Reviews. Journa of Retailing. 598-612. Doi: 10.1016/j.jretai.2011.05.002.

Pourabedin, Z. \& Migin, W.M. (2015). Hotel Experience and Positive Electronic Word of Mouth (eWOM). Journal International Business Management. 596-600.

Silverman, G. (2001). The Secrets of Word of Mouth Marketing. New York: American Management Association.

Siregar, S. (2013). Statistik Parametrik Untuk Penelitian Kuantitatif. Jakarta: Bumi Aksara.

Sundaram, D.S., Mitra, K., \& Webster, C. (1998). WordOf-Mouth Communications: a Motivational Analysis. Advances in Consumer Research, 25: 527-531.

WuP.C. \&WangY-C.(2011).TheInfluences of Electronic Word of Mouth Message Appeal and Message Source Credibility on Brand Attitude. Asia Pasific Journal of Marketing and Logistic, 23( 4): 448472. DOI: $10.1108 / 13555851111165020$.

Yoo, K. H. \& Gretzel, U. (2008). What Motivates Consumers to Write Online Travel Reviews. Information Teknology and Tourism, 10: 283295. 